\title{
Biochemical Evaluation of Fermented White Maize (Zea Mays L.) Blended with Scarlet Runner Bean (Phaseolus Coccineus L.) Flour
}

\author{
M. O. Aremu ${ }^{a, *}$, O. Olaofe ${ }^{b}$, S. S. Audu ${ }^{a}$ and D. M. Ijalana ${ }^{a}$ \\ ${ }^{a}$ Department of Chemistry, Nasarawa State University, PMB 1022, Keffi, Nigeria \\ ${ }^{b}$ Department of Chemistry, University of Ado-Ekiti, PMB 5363, Ado-Ekiti, Nigeria
}

\begin{abstract}
Fermented maize product, ogi, is a popular weaning and breakfast cereal in west coasts of Africa. In the study proximate, mineral and amino acid compositions of ogi from a composite mixture of white maize (Zea mays L.) and scarlet runner bean (Phaseolus coccineus L.) flours were evaluated using standard processing techniques. Maize ogi was substituted with scarlet runner bean flour at ratios of 90:10, 80:20, 70:30 and 60:40 maize : scarlet runner bean; with $100 \%$ maize ogi flour as control. The results showed that protein, ash and crude fibre contents increased progressively with increased scarlet runner bean flour substitution, reaching $192.0 \%, 187.5 \%$ and $170.0 \%$ dry weight, respectively at 60:40 ratio. The macro minerals such as $\mathrm{Mg}, \mathrm{Na}$ and $\mathrm{P}$ also recorded increase in concentrations in the fortified products. Harmful heavy metals like $\mathrm{Pb}$ and $\mathrm{Cd}$ were below detection limit of the AAS. The total essential amino acids (TEAA) ranged from $20.37-27.59 \mathrm{~g} / 100 \mathrm{~g}$ crude protein or from $41.40-43.10 \%$ of the total amino acid while the limiting amino acid (LAA) was Met + Cys. It was also found that fortified samples had progressive increase in the concentration levels of total amino acid (TAA), total essential amino acid (TEAA), essential aromatic amino acid (EArAA) and total sulphur amino acid (TSAA). Generally, the present study indicates that at $\leq 40 \%$ scarlet runner bean seed substitution of the ogi mass, the quality attributes of ogi can be maintained, with higher nutrient content.
\end{abstract}

Keywords: Maize ogi, scarlet runner bean, nutritional quality.

\section{INTRODUCTION}

Scientifically, it has been proved that breast milk is the perfect food for the infant during the first six months of life. It contains all the nutrients and immunological factors an infant requires to maintain optimal health and growth. Furthermore, breast milk also protects infants against the two leading causes of infant mortality, upper respiratory infections and diarrhea [1]. However, at the age of six months and above when the child's birth weight is expected to have doubled, breast milk is no longer sufficient to meet the nutritional needs of the growing infant. Nutritious complementary foods are therefore introduced, also known as weaning foods which typically covers the period from six to twenty-four months of age in most developing countries [2]. But nowadays due to the reduced consumption of breast milk, important nutrients such as proteins, zinc, iron and B-vitamins are likely to be deficient in the contemporary diet of the affected infants [3]. If such a development is not well handled during this crucial growth period, it can lead to under-nutrition. For instance, poor feeding practices and/or shortfall in food intake have been identified as the most important direct factors responsible for malnutrition and illness amongst children in Nigeria [4].

As in most other developing countries the high cost of fortified nutritious a complementary food is always, if not

*Address correspondence to this author at the Department of Chemistry, Nasarawa State University, PMB 1022, Keffi, Nigeria; Tel: +2348065611658; E-mail: lekearemu@gmail.com prohibitive, beyond the reach of most Nigerian families. Such families often depend on inadequately processed traditional foods consisting mainly of un-supplemented cereal porridges made from maize, sorghum and millet. In view of this, appropriate processing and blending of locally available food commodities have been carried out and researched into by a number of researchers [5-8]. This approach requires knowledge about the nutritive values of a variety of local food commodities, indigenous to the affected communities. A number of cereals and legumes that are readily available in Nigeria have been found to have nutrient potentials that could complement one another if properly processed and blended [9-11]. Therefore, it is imperative that efforts to formulate composite blends and scientific studies are carried out to ascertain the nutritive adequacy of these locally available blends (cereal and legumes) for possible use as complementary foods, especially by the rural and poor urban mothers during weaning period.

Fermented maize product, ogi, is a popular weaning and breakfast cereal in sub-Saharan Africa [6]. Ogi is traditionally prepared by natural fermentation (steeping maize grains in water for $2-4$ days at room temperature), followed by wet milling, sieving and souring slurry $(2-3$ days rest at room temperature). The periods of fermentation and souring determine the degree of sourness (measured by titratable acidity) acids, to a large extent, the nutrient status of ogi [7]. Scarlet runner bean (Phaseolus coccineus L.) is an unconventional legume which was found to have contained nutritionally useful quantities of most of the essential amino acids 
and adequate amounts of the limiting amino acids [12] and also good sources of essential minerals [13]. The objective of the present study was to assess proximate, mineral and amino acid compositions of fermented white maize (Zea mays L.) ogi blended with scarlet runner bean (Phaseolus coccineus L.) flour with a view to providing preliminary information towards utilization of this legume in various food applications in Africa.

\section{MATERIALS AND METHODS}

\section{Samples Collection and Preparation}

Scarlet runner bean (Phaseolus coccineus L.) and with maize grains (Zea mays L.) used for the study were purchased from Garaku market in Kokona local government of Nasarawa State, Nigeria. The scarlet runner bean seed flour and maize ogi were produced in the laboratory as outlined in Fig. (1). Wet milling was done using laboratory Kenwood blender (Mini-Processor Model A90LD, Thom Emi Kenwood Small Appliance Ltd., Hampshire, UK) while milling of the flours was done using Hammer Mill, to pass through a $0.25 \mathrm{~mm}$ screen. The dehulled parboiled scarlet runner bean seed flour was added to maize flour at substitution levels of 10, 20, 30 and 40\%, respectively; $100 \%$ maize flour served as control. The blended flours were then packaged in moisture-proof, air-tight polyethylene containers and kept at $4^{\circ} \mathrm{C}$ prior to analyses.

\section{Proximate Analyses}

The moisture, ash, ether extract, crude fibre, crude protein ( $\mathrm{N} \times 6.25)$ and carbohydrate (by difference) were determined in accordance with AOAC methods [14]. All proxi-

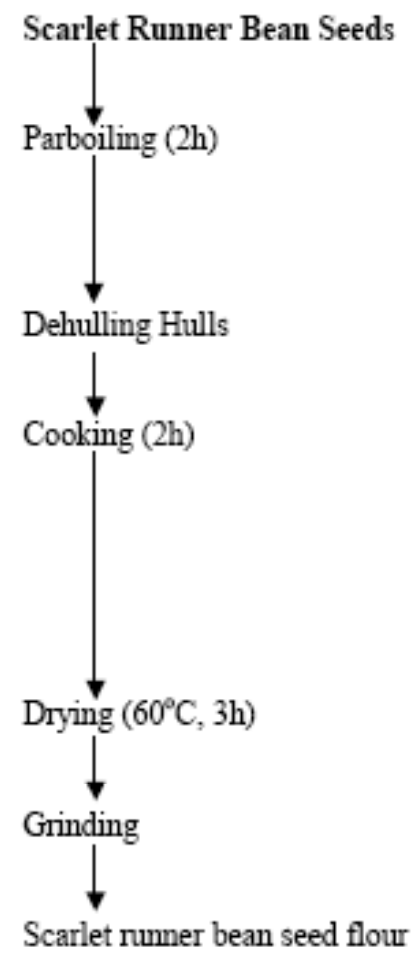

(a) mate analyses of the sample flours were out in triplicate and reported in \%. All chemicals were of Analar grade.

\section{Mineral Analysis}

Sodium and potassium were determined using a flame photometer (Model 405, Corning UK). Phosphorus was determined by Vanadomolybdate colourimetric method [15]. All other metals were determined by Atomic Absorption Spectrophotometer (Perkin-Elmer model 403, Norwalk CT). The minerals were reported in $\mathrm{mg} / 100 \mathrm{~g}$ sample.

\section{Amino Acid Analysis}

The amino acids were quantitatively measured by procedure described by Spackman [16], using automatic amino acid analyzer (Technicon TSM Sequential Multisample Analyzer). Sample was hydrolyzed for determination of all amino acids except trytophan in consistent boiling hydrochloric acid for $22 \mathrm{~h}$ under a nitrogen flux.

\section{Estimation of Isoelectric Point (pI) Quality of Dietary} Protein and Predicted Protein Efficiency Ratio (P-PER)

The predicted isoelectric point was evaluated as follows [17]:

$p \operatorname{Im}=\sum_{i=1}^{n=1} p I i X i$

Where: $\mathrm{pIm}$ is the isoelectric point of the mixture of amino acids, $\mathrm{pI}_{\mathrm{i}}$ is the isoelectric point of the $\mathrm{i}^{\text {th }}$ amino acids in the mixture, and $X_{i}$ is the mass or mole fraction of the amino acids in the mixture.

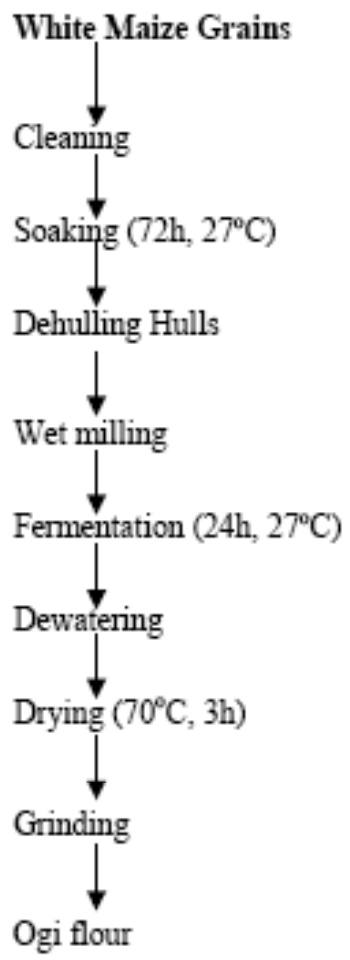

(b)

Fig. (1). Processing methods adapted for the production of (a) Scarlet runner bean and (b) Maize ogi flours. 
The quality of dietary protein was measured by finding the ratio of available amino acids in the flour sample with need expressed as a ratio [18]. Amino acid score (AAS) was then estimated by applying the following formula [19]:

$A A S=\frac{m g \text { of } a \text { min } o \text { acid in } \lg \text { of test protein }}{m g \text { of a } \min \text { o acid in } \lg \text { of reference protein }} \times \frac{100}{1}$

The predicted protein efficiency ratio (P-PER) of fortified flour was calculated from their amino acid composition based on the equation developed by Alsmeyer et al. [20]:

P-PER $=-0.468+0.454($ Leu $)-0.105$ (Tyr)

\section{Calculations and Statistical Analyses}

Sodium/potassium $(\mathrm{Na} / \mathrm{K})$ and calcium/phosphorus $(\mathrm{Ca} / \mathrm{P})$ ratios were calculated for the samples [21]. Standard deviations were calculated using MS Excel Spread Sheet from the three determinations done on each sample for the proximate composition and was used as the measure of dispersion.

\section{RESULTS AND DISCUSSION}

The proximate composition of maize ogi fortified with scarlet runner bean flour is presented in Table 1. Increased scarlet runner bean flour substitution gave progressively higher protein, crude fibre and ash contents of the product with lower fat and carbohydrate contents. It has been reported [7] that the traditional method of ogi processing is usually accompanied by severe nutrient losses, which aggravates the poor nutritional quality of normal dent corn. There was progressive decrease in moisture content of the fortification product; this could mean a reduction in pre-disposition to shelf spoilage [23]. Though, there was progressive decrease in the calculated metabolizable energy values of scarlet runner bean substituted maize ogi flours but difference in each product not significant $(P>0.05)$. Scarlet runner bean is known to have containing energy concentration favourably compare to cereal [10]. Despite the effect of fortification processes the coefficient of variation (CV\%) levels were relatively close with hot spot at 45.8 in ash content whereas others ranged from 1.1 in energy to 32.8 in crude fibre.

Differences in the mean proximate composition between maize ogi and different fortification products are presented in Table 2. The parameters that increased progressively with different fortification products were ash, crude fibre and crude protein with percentage range values of $20.0-$ $187.5 \%, 40.0-170.0 \%$ and $47.1-192.0 \%$, respectively while the ones that decreased were moisture, crude fat, carbohydrate, calculated fatty acid and calculated metabolizable energy with range values of $8.6-25.5 \%, 7.3-22.0 \%, 3.8-$ $17.7 \%, 7.3-21.95$ and $0.5-3.1 \%$, respectively. The CV\% was variously varied with a range of $27.4-60$ Table 2 .

The mineral composition of the weaning diets is presented in Table 3. The macro-minerals such as $\mathrm{P}, \mathrm{Mg}$ and $\mathrm{Na}$ recorded increased concentrations in the maize ogi with increased scarlet runner bean flour substitutions while $\mathrm{Ca}$ and $\mathrm{K}$ decreased in concentrations with increased substitution ratios. However, $\mathrm{Ca}$ maintain the same concentration of $108.10 \mathrm{mg} / 100 \mathrm{~g}$ at $90: 10$ substitution ratio with $100 \%$ maize ogi (control). Magnesium is an important element in connection with circulatory diseases such as ischemic heart disease and calcium metabolism in bone [24]. Calcium in conjunction with phosphorus, magnesium, vitamin A, C and D, chlorine and protein are all involved in bone formation [25]. Calcium is also important in blood clotting, muscle contraction and in certain enzymes in metabolic processes [25]. Phosphorus assists calcium in many body reactions although it also has independent function.

Modern diets which are rich in animal proteins and phosphorus may promote the loss of calcium in the urine [26]. Among the micro-minerals, only $\mathrm{Zn}$ and $\mathrm{Fe}$ had a decrease in concentrations at 90:10 \& 80:20 and 90:10 substitution ratios, respectively while others $(\mathrm{Cr}, \mathrm{Co}, \mathrm{Cu}$ and $\mathrm{Mn})$ increased in concentrations. Nickel was only detected at 80:20 of

Table 1. Mean Proximate Composition (\%) of Maize Ogi Fortified with Scarlet Runner Bean Flour

\begin{tabular}{|c|c|c|c|c|c|c|c|c|}
\hline Parameter & $\begin{array}{c}100 \% \\
\text { Maize Ogi }\end{array}$ & $\begin{array}{c}\text { Maize : SRB } \\
90: 10\end{array}$ & $\begin{array}{c}\text { Maize : SRB } \\
80: 20\end{array}$ & $\begin{array}{c}\text { Maize : SRB } \\
70: 30\end{array}$ & $\begin{array}{c}\text { Maize : SRB } \\
60: 40\end{array}$ & Mean & SD & CV\% \\
\hline Moisture & $4.43(0.10)^{\mathrm{a}}$ & $4.05(0.50)$ & $3.80(0.20)$ & $3.55(2.05)$ & $3.30(0.10)$ & 3.83 & 0.39 & 10.2 \\
\hline Ash & $0.80(0.50)$ & $0.96(0.20)$ & $1.41(0.10)$ & $1.75(2.50)$ & $2.30(0.20)$ & 1.44 & 0.66 & 45.8 \\
\hline Crude fat & $4.10(0.20)$ & $3.80(0.50)$ & $3.70(0.50)$ & $3.50(0.01)$ & $3.20(0.20)$ & 3.66 & 0.30 & 8.2 \\
\hline Crude fibre & $1.00(0.00)$ & $1.40(1.20)$ & $1.90(0.20)$ & $2.30(0.05)$ & $2.70(0.20)$ & 1.86 & 0.61 & 32.8 \\
\hline Crude protein & $7.00(0.50)$ & $10.30(0.20)$ & $13.67(0.15)$ & $16.11(0.10)$ & $20.44(1.00)$ & 13.50 & 3.79 & 28.1 \\
\hline Carbohydrate $^{\mathrm{b}}$ & $82.67(0.50)$ & $79.49(0.10)$ & $75.52(2.10)$ & $72.79(0.30)$ & $68.09(2.10)$ & 75.70 & 5.10 & 6.7 \\
\hline Fatty acid ${ }^{\mathrm{c}}$ & $3.28(0.20)$ & $3.04(0.50)$ & $2.96(0.50)$ & $2.80(5.05)$ & $2.56(1.20)$ & 2.93 & 0.20 & 6.8 \\
\hline Energy $^{\mathrm{d}}$ & $1676.09(5.10)$ & $1667.03(6.50)$ & $1653.13(2.35)$ & $1640.80(2.50)$ & $1623.41(4.50)$ & 1652.09 & 18.7 & 1.1 \\
\hline
\end{tabular}

${ }^{\mathrm{a}}$ Number in parentheses are standard deviations of triplicate determinations

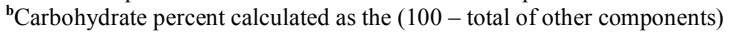

${ }^{\mathrm{c}}$ Calculated fatty acids $(0.8 \times$ crude fat $)$

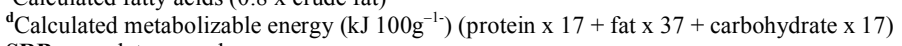

$\mathbf{S R B}=$ scarlet runner bean 
Table 2. Differences in the Mean Proximate Composition Between Maize Ogi and Different Fortified Products

\begin{tabular}{|c|c|c|c|c|c|c|c|}
\hline Moisture & $0.38(8.6 \%)$ & $0.63(14.2 \%)$ & $0.88(19.9 \%)$ & $1.13(25.5 \%)$ & 0.76 & 0.38 & 50.0 \\
\hline Crude fat & $0.30(7.3 \%)$ & $0.4(9.8 \%)$ & $0.60(14.6 \%)$ & $0.9(22.0 \%)$ & 0.55 & 0.22 & 40.0 \\
\hline Crude fibre & $-0.40(-40.0 \%)$ & $0.90(90.0 \%)$ & $-1.30(-130.0 \%)$ & $-1.2(-170.0 \%)$ & 0.95 & 0.26 & 27.4 \\
\hline Carbohydrate & $3.10(3.8 \%)$ & $7.15(8.6 \%)$ & $9.98(11.9 \%)$ & $14.62(17.7 \%)$ & 8.69 & 4.19 & 48.2 \\
\hline Fatty acid & $0.24(7.3 \%)$ & $0.32(9.8 \%)$ & $0.48(14.6 \%)$ & $0.72(21.9 \%)$ & 0.44 & 0.18 & 40.9 \\
\hline Energy kJ. & $9.06(0.5 \%)$ & $22.96(1.4 \%)$ & $35.29(2.1 \%)$ & $52.69(3.1 \%)$ & 30.0 & 16.1 & 53.5 \\
\hline
\end{tabular}

$\mathbf{I}=100 \%$ maize ogi; $\mathbf{I I}=90$ maize ogi:10 SRB; $\mathbf{I I I}=80$ maize ogi:20 SRB; IV = 70 maize ogi:30 SRB; $\mathbf{V}=60$ maize ogi:40 SRB; $\mathbf{S R B}=$ scarlet runner bean; SD = standard deviation; $\mathbf{C V}=$ coefficient of variation.

Table 3. Mean Mineral Composition (mg/100g) of Maize Ogi Fortified with Scarlet Runner Bean Flour

\begin{tabular}{|c|c|c|c|c|c|c|c|c|}
\hline Mineral & I & II & III & IV & V & Mean & SD & CV\% \\
\hline $\mathrm{Ca}$ & 108.10 & 76.40 & 79.30 & 67.53 & 108.10 & 87.89 & 18.96 & 21.6 \\
\hline $\mathrm{Cr}$ & 2.56 & 2.77 & 4.33 & 4.74 & 5.75 & 4.03 & 1.21 & 30.0 \\
\hline $\mathrm{Co}$ & ND & 14.13 & 16.43 & 18.30 & 11.70 & 12.11 & 3.50 & 28.9 \\
\hline $\mathrm{Cd}$ & ND & ND & ND & ND & ND & - & - & - \\
\hline $\mathrm{P}$ & 37.89 & 49.05 & 37.26 & 47.15 & 50.49 & 44.37 & 5.65 & 12.7 \\
\hline $\mathrm{Zn}$ & 4.93 & 4.61 & 4.32 & 5.47 & 5.46 & 4.96 & 0.46 & 9.3 \\
\hline $\mathrm{Cu}$ & ND & 2.45 & 4.26 & 6.46 & 8.38 & - & - & - \\
\hline $\mathrm{Mn}$ & 0.88 & 1.16 & 1.54 & 1.74 & 2.39 & 1.54 & 0.52 & 33.8 \\
\hline $\mathrm{Ni}$ & ND & ND & 0.06 & ND & ND & - & - & - \\
\hline $\mathrm{Fe}$ & 18.10 & 16.39 & 18.68 & 21.56 & 21.38 & 19.22 & 1.99 & 10.4 \\
\hline $\mathrm{Mg}$ & 77.11 & 170.08 & 211.11 & 244.08 & 231.61 & 186.80 & 60.32 & 32.3 \\
\hline $\mathrm{K}$ & 21.00 & 14.80 & 17.20 & 20.00 & 20.00 & 18.6 & 2.28 & 12.3 \\
\hline $\mathrm{Na}$ & 53.80 & 53.86 & 67.50 & 50.00 & 68.52 & 58.74 & 7.71 & 13.1 \\
\hline $\mathrm{Pb}$ & ND & ND & ND & ND & ND & - & - & - \\
\hline $\mathrm{Ca} / \mathrm{P}$ & 2.90 & 1.60 & 2.12 & 1.43 & 2.14 & 2.04 & 0.51 & 25.0 \\
\hline $\mathrm{Na} / \mathrm{K}$ & 2.56 & 3.64 & 3.92 & 2.50 & 3.43 & 3.21 & 0.57 & 17.8 \\
\hline
\end{tabular}

$\mathbf{N D}=$ not detected $; \mathbf{N a} / \mathbf{K}=$ sodium to potassium ratio $; \mathbf{C a} / \mathbf{P}=$ calcium to phosphorus ratio; $\mathbf{S D}=$ standard deviation; $\mathbf{C V}=$ coefficient of variation; $-=$ not determined; $\mathbf{I}=100 \%$ maize ogi; II = 90 maize ogi:10 SRB; III = 80 maize ogi:20 SRB; IV = 70 maize ogi:30 SRB; V = 60 maize ogi:40 SRB; $\mathbf{S R B}=$ scarlet runner bean

maize ogi to scarlet runner bean flour substitution ratio. It is interesting to note that harmful minerals such as $\mathrm{Cd}$ and $\mathrm{Pb}$ were not at detectable range of AAS for any of the samples Table 3. Cadmium and lead even at low concentration are known to be toxic and have no known function in biochemical process. Lead can impair the nervous system and affect foetus, infants and children resulting in lowering of intelligent quotient (IQ) even at its lowest dose [27]. Coefficient of variation percent levels of all the minerals were also rela- tively close with the highest found in Mn (33.8) while the least was $\mathrm{Zn}$ (9.3).

Differences in the mean mineral composition between $100 \%$ maize ogi (control) and different scarlet runner bean flour substitutions showed that CV\% ranged from 20.0 in $\mathrm{Zn}$ to 72.3 in K Table 4. Overall, it could be concluded that substitution of maize with scarlet runner bean in the production of ogi yields fortified products with improved valuable mineral content. This is also substantiated by the increased 
Table 4. Differences in the Mean Mineral Composition Between Maize Ogi and Different Fortified Products

\begin{tabular}{|c|c|c|c|c|c|c|c|}
\hline $\mathrm{Ca}$ & $31.70(29.3 \%)$ & $28.80(26.6 \%)$ & $40.57(37.5 \%)$ & $0.00(0.0 \%)$ & 25.27 & 8.50 & 33.6 \\
\hline Co & - & - & - & - & - & - & - \\
\hline $\mathrm{Cd}$ & - & - & - & - & - & - & - \\
\hline $\mathrm{Zn}$ & $0.32(6.5 \%)$ & $0.61(12.4 \%)$ & $-054(11.0 \%)$ & $-0.53(10.8 \%)$ & 0.50 & 0.10 & 20.0 \\
\hline $\mathrm{Cu}$ & - & - & - & - & - & - & - \\
\hline $\mathrm{Mn}$ & $-0.28(-31.8 \%)$ & $-0.66(-75.0 \%)$ & $-0.86(-97.7 \%)$ & $-1.51(-171.6 \%)$ & 0.83 & 0.45 & 54.2 \\
\hline K & $6.20(29.5) \%$ & $3.80(18.1 \%)$ & $1.00(4.8 \%)$ & $1.60(4.8 \%)$ & 3.00 & 2.17 & 72.3 \\
\hline $\mathrm{Na}$ & $-0.06(-0.1 \%)$ & $-13.7(-25.5 \%)$ & $3.80(7.1 \%)$ & $-14.72(-27.4 \%)$ & 8.07 & 5.66 & 70.1 \\
\hline $\mathrm{Pb}$ & - & - & - & - & - & - & - \\
\hline $\mathrm{Ca} / \mathrm{P}$ & $1.3(44.8 \%)$ & $0.78(26.9 \%)$ & $1.47(50.7 \%)$ & $0.76(26.2 \%)$ & 1.08 & 0.55 & 50.9 \\
\hline $\mathrm{Na} / \mathrm{K}$ & $-1.08(-42.2 \%)$ & $-1.36(-53.1 \%)$ & $0.06(2.3 \%)$ & $0.42(16.4 \%)$ & 0.73 & 0.52 & 71.2 \\
\hline
\end{tabular}

$\mathbf{I}=100 \%$ maize ogi; $\mathbf{I I}=90$ maize ogi:10 SRB; $\mathbf{I I I}=80$ maize ogi:20 SRB; $\mathbf{I V}=70$ maize ogi:30 SRB; $\mathbf{V}=60$ maize ogi:40 SRB; SRB = scarlet runner bean; SD = standard deviation; $\mathbf{C V}=$ coefficient of variation; $-=$ not determined

ash content at all substitution levels Table 1. Some workers $[7,28]$ also observed significant increase in ash and mineral contents in African oil bean - ogi and pawpaw - ogi, respectively. The scarlet runner bean is known to contain appreciable amounts of important minerals $[10,12]$, and this is expected to reflect in any legume - based or supplemented food product. Food is considered "good" if $\mathrm{Ca} / \mathrm{P}$ ratio is above one and "poor" if the ratio is less that 0.5 while $\mathrm{Ca} / \mathrm{P}$ ratio above two helps to increase the absorption of calcium on the small intestine. The results of $\mathrm{Ca} / \mathrm{P}$ ratios in ogi sample and fortified products Table 3 were not only good but also gave an indication that they would help to increase the absorption of calcium in the small intestine.

Table 3 also shows $\mathrm{Na} / \mathrm{K}$ ratios of $100 \%$ maize ogi and fortified products. Both $\mathrm{Na}$ and $\mathrm{K}$ are required to maintain osmotic balance of body fluid and the $\mathrm{pH}$ of the body regulate muscle and nerve irritability, control glucose absorption and enhance normal retention of protein during growth [21]. $\mathrm{The} \mathrm{Na} / \mathrm{K}$ ratio less than one is recommended. Sodium to potassium ratios in this report ranged from 2.50 to 3.64 $\mathrm{mg} / 100 \mathrm{~g}$ sample $(\mathrm{CV} \%, 17.8)$; these values are greater than one, hence the samples may not have capacity to hinder blood pressure [21].

Amino acid profile is presented in Table 5. Leucine was the most concentrated (5.00 to $6.56 \mathrm{~g} / 100 \mathrm{~g}$ crude protein) essential amino acid in all the samples (both control and fortified samples) while glutamic acid was the most concentrated amino acid (6.54 to $8.88 \mathrm{~g} / 100 \mathrm{~g}$ crude protein, $\mathrm{cp})$ as expected in legumes $[29,30]$. Tryptophan concentrations could not be determined. Increased scarlet runner bean substitution gave progressive higher concentrations of all the essential amino acids (AA) though His, Arg and Thr recorded reduction only in 90:10 substitution ratio. Levels of CV\% ranged from 7.6 in Gly to 53.4 in Cys. Differences in the mean amino acid composition between maize ogi (100\%) and fortified products revealed that there was progressive increase of all the AA from 80:20 to 60:40 substitutions except Pro which had decrease of $4.9 \%$ at $70: 30$ substitution ratio Table 6. At 90:10 scarlet runner bean - substituted maize ogi flours, four AAs that were reduced in concentraton were His, Arg, Thr and Pro with percentage values of 4.0, $21.5,1.8$ and $9.4 \%$, respectively. The CV\% was variously varied with a range of 11.9 in Met to 100.0 in Thr. Highlights of the increases recorded in EAA were (in \%): Lys (3.3 - 33.4), His (28.4 - 31.8), Arg (14.8 - 27.8), Thr (2.7 37.0), Val (15.7 - 33.7), Met (4.2 - 42.1), Ile (23.9 - 62.0), Leu (8.8 - 31.2), Tyr (18.1 - 27.1) and Phe (15.9-35.2).

The concentrations of total AA (TAA), total nonessential AA (TNAA), total essential AA (TEAA) with His, essential alphatic AA (EAAA), essential aromatic AA (EArAA) and total sulphur AA (TSAA) of $100 \%$ maize ogi (control) were 49.20, 28.83, 20.37, 11.93, 2.70 and 1.10 $\mathrm{g} / 100 \mathrm{~g} \mathrm{cp}$, respectively Table 7 . Fortified samples had progressive increase in the concentration levels of TAA, TNEAA, TEAA, EAAA, EArAA and TSAA. The TAA in this report $(40.20-64.01 \mathrm{~g} / 100 \mathrm{~g} \mathrm{cp})$ are close to the TAA in the bambara groundnut $(68.5 \mathrm{~g} / 100 \mathrm{~g} \mathrm{cp})$ [13] and dehulled African yam beans $(70.3 \mathrm{~g} / 100 \mathrm{~g} \mathrm{cp})$ [11]. The contents of 
Table 5. Amino Acid Profiles of Maize Ogi Fortified With Scarlet Runner Bean Flour (g/100g Crude Protein)

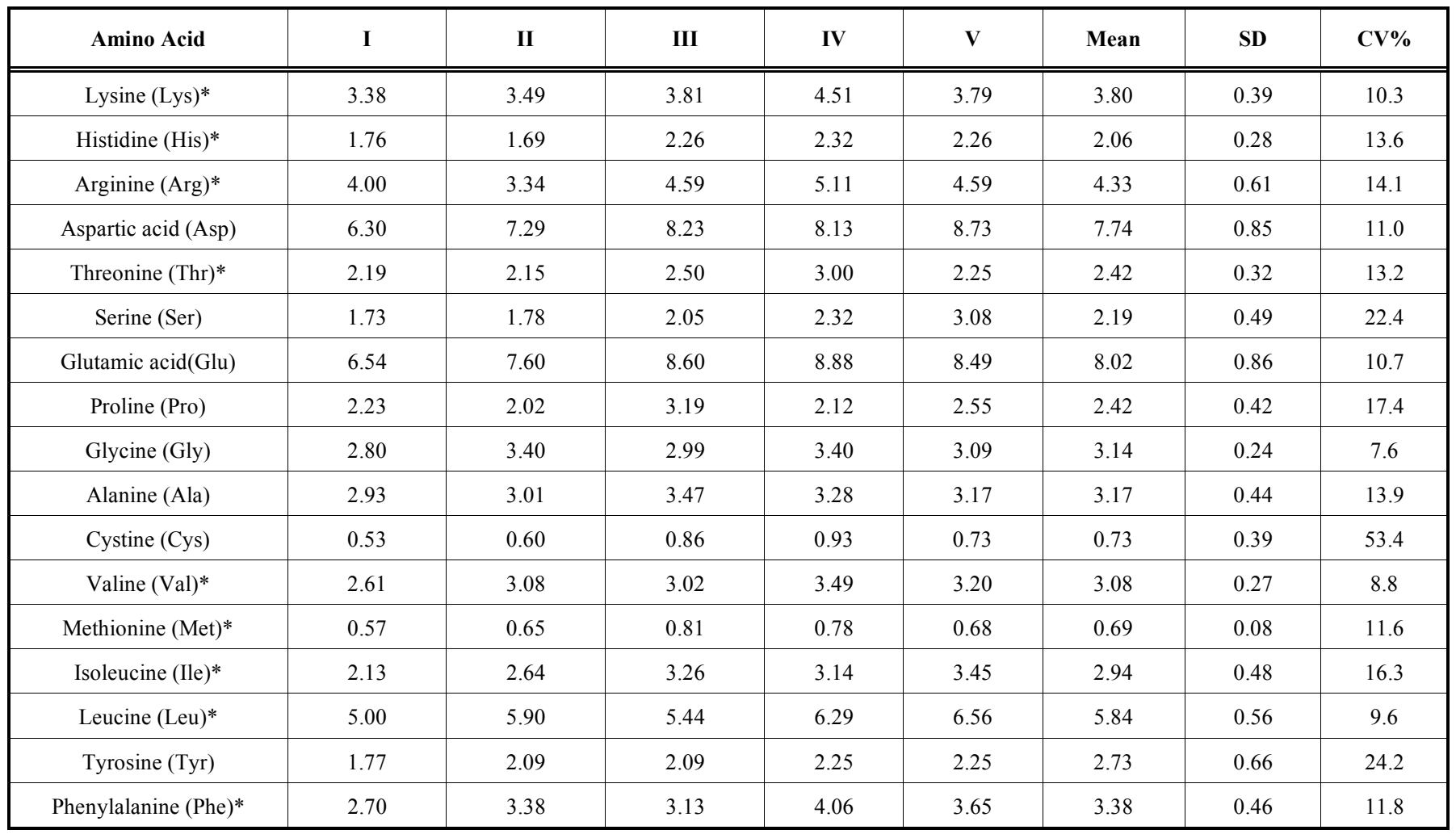

*Essential amino acids; I = 100\% maize ogi; II = 90 maize ogi:10 SRB; III = 80 maize ogi:20 SRB; $\mathbf{I V}=70$ maize ogi:30 SRB; $\mathbf{V}=60$ maize ogi:40 SRB; SRB = scarlet runne bean; $\mathbf{S D}=$ standard deviation; $\mathbf{C V}=$ coefficient of variation

Table 6. Differences in the Mean Amino Acid Composition Between Maize Ogi and Different Fortified Products

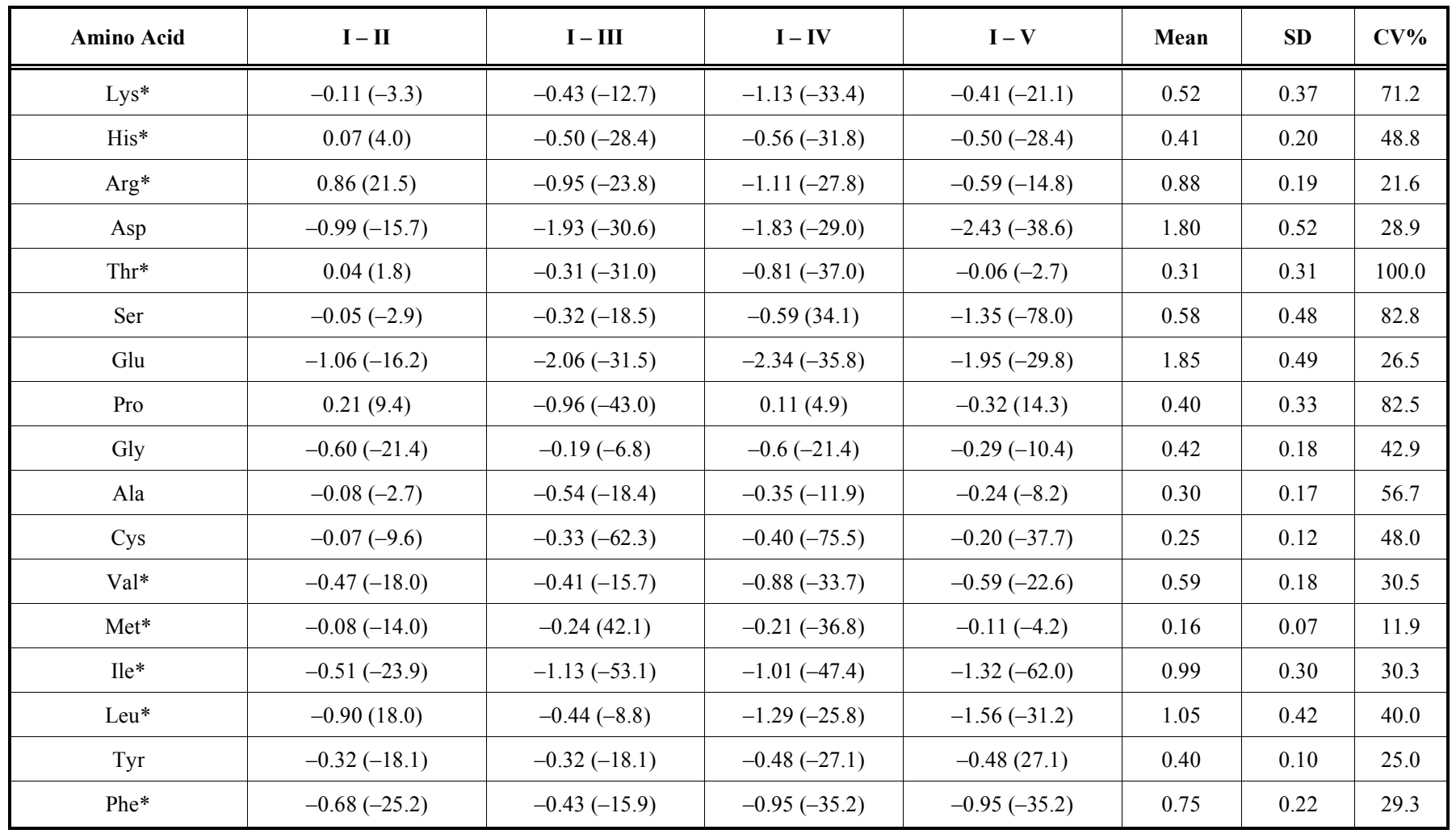

*Essential amino acids; I = 100\% maize ogi; $\mathbf{I I}=90$ maize ogi:10 SRB; III = 80 maize ogi:20 SRB; IV = 70 maize ogi:30 SRB; V = 60 maize ogi:40 SRB; SRB = scarlet runner bean; $\mathbf{S D}=$ standard deviation; $\mathbf{C V}=$ coefficient of variation. 
Table 7. Concentrations of Essential, Non-Essential, Acidic, Neutral, Sulphur, Aromatic, etc. (g/100g Crude Protein) of Maize Ogi Fortified With Scarlet Runner Bean Flour

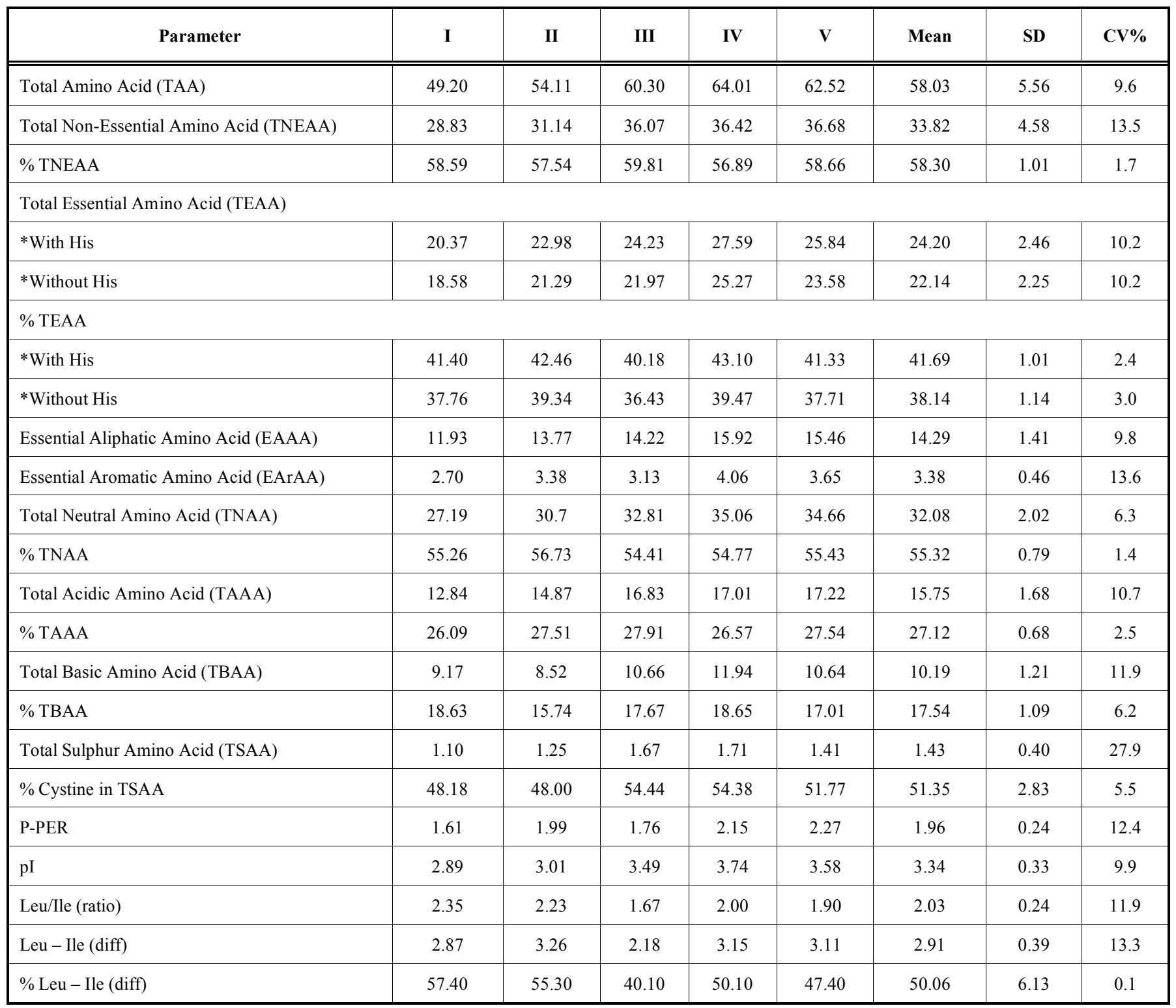

*Essential amino acids; I = 100\% maize ogi; $\mathbf{I I}=90$ maize ogi:10 SRB; III = 80 maize ogi:20 SRB; IV = 70 maize ogi:30 SRB; $\mathbf{V}=60$ maize ogi:40 SRB; SRB = scarlet runner bean; $\mathbf{S D}=$ standard deviation; $\mathbf{C V}=$ coefficient of variation.

TSAA $(1.10-1.71 \mathrm{~g} / 100 \mathrm{~g} \mathrm{cp})$ are lower than the $5.8 \mathrm{~g} / 100 \mathrm{~g}$ cp recommended for infants [31]. The EArAA range suggested for ideal infant protein $(6.8-11.8 \mathrm{~g} / 100 \mathrm{~g} \mathrm{cp})$ [31] has current values close to the minimum, i.e. $2.70-4.06 \mathrm{~g} / 100 \mathrm{~g}$ $\mathrm{cp}$. The EArAA are precursors of epinephrine and thyroxin [32]. The percentage ratios of TEAA to TAA in the samples ranged from 41.40 to $43.10 \%$ which are well above the $39 \%$ considered to be adequate for ideal protein food for infants, $26 \%$ for children and $11 \%$ for adults [31]. The TEAA/TAA percentage contents are close to that of egg (50\%) [19], and well comparable with $43.6 \%$ reported for pigeon pea flour [33], 43.8\% for beach pea protein isolate [34] and $40.6 \%$ reported for cashew nut [35]. The predicted protein efficiency ratio (P-PER) is one of the quality parameter used for protein evaluation [19]. The P-PER values in this report Table 7 are higher than cowpea (1.21) and sorghum ogi
(0.27) [6] but comparable with millet ogi (1.62) [6] and pigeon pea (1.82) [33].

The presence of D-isomers also reduces the digestibility of the protein because peptide bonds involving D residues are less easily hydrolyzed in vivo than those containing only $\mathrm{L}$ residues. Moreover, certain $\mathrm{D}$ amino acids exert a toxic action, in proportion to the amount absorbed through the intestinal wall [36]. This elucidates a word of caution on the excessive consumption of maize ogi or its fortified products. A common feature of sorghum and maize is that the proteins of these grains contain a relatively high proportion of leucine. It was therefore suggested that an amino acid imbalance from excess leucine might be a factor in the development of pellagra [37]. Clinical, biochemical and pathological observations in experiments conducted in humans and laboratory animals showed that high leucine in the diet impairs 
Table 8. Amino Acid Scores of Maize Ogi Fortified with Scarlet Runner Bean Flour

\begin{tabular}{|c|c|c|c|c|c|c|c|c|c|c|c|}
\hline EAA & $\begin{array}{c}\text { PAAESP }^{\mathrm{a}} \\
\text { (g/100g Protein) }\end{array}$ & EAAC & EAAS & EAAC & EAAS & EAAC & EAAS & EAAC & EAAS & EAAC & EAAS \\
\hline Leu & 7.0 & 5.00 & 0.71 & 5.90 & 0.84 & 5.44 & 0.77 & 6.29 & 0.89 & 6.56 & 0.93 \\
\hline Lys & 5.5 & 3.38 & 0.61 & 3.49 & 0.63 & 3.81 & 0.69 & 4.51 & 0.82 & 3.79 & 0.69 \\
\hline Phe + Tyr & 6.0 & 4.47 & 0.78 & 5.47 & 0.91 & 5.22 & 0.87 & 6.31 & 1.05 & 5.90 & 0.98 \\
\hline Thr & 4.0 & 2.19 & 0.55 & 2.15 & 0.54 & 2.50 & 0.63 & 3.00 & 0.75 & 2.25 & 0.56 \\
\hline Try & 1.0 & - & - & - & - & - & - & - & - & - & - \\
\hline
\end{tabular}

EAA = essential amino acid; PAAESP = provisional amino acid (egg) scoring pattern; $\mathbf{E A A C}=$ essential amino acid composition $($ see Table 5); EAAS $=$ essential amino acid score - = not determined; I = 100\% maize ogi; II = 90 maize ogi:10 SRB; III = 80 maize ogi:20 SRB; IV = 70 maize ogi:30 SRB; V= 60 maize ogi:40 SRB; SRB = scarlet runner bean; $\mathbf{S D}=$ standard deviation; $\mathbf{C V}=$ coefficient of variation; ${ }^{\text {a Source }}=$ Belschant et al. [22].

the metabolism of tryptophan and niacin and is responsible for niacin deficiency in sorghum eaters [38]. High leucine is also a factor contributing to the pellagragenic properties of maize [39]. These studies suggested that the leucine/ isoleucine balance is more important than dietary excess of leucine alone in regulating the metabolism of tryptophan and niacin and hence the disease process. The present Leu/Ile ratios were low in values $(1.67-2.35)$ Table 7 . The calculated isoelectric point (pI) ranged from 2.89 to 3.74 . This is useful in predicting the $\mathrm{pI}$ for protein in order to enhance a quick precipitation of protein isolate from biological samples [17]. The highest variability was TSAA (CV\%, 27.9) while the least was percentage of Leu to Ile difference (CV\%, 0.1) Table 7 .

The EAA scores (EAAS) of the samples based on the provisional amino acid scoring pattern [19] are shown in Table 8. The EAAS greater than 1.0 was Phe + Try for $70: 30$ substitution ratio sample. This shows that supplementation may be required in Ile, Leu, Lys, Met + Cys (TSAA), Thr and Val for all the fortified products. However, EAAS based on $\mathrm{FAO} / \mathrm{WHO} / \mathrm{UNU}$ [31] standards for the infants with a required value of $1.9 \mathrm{~g} / 100 \mathrm{~g} \mathrm{cp}$ for His, showed that fortified samples of $80: 20,70: 30$ and $60: 40$ substitution ratios had scores of His more than 1.0 Table 5. Histidine is a semiessential AA particularly useful for children growth. It is the precursor of histidine present in small quantities in cells. When allergens enter the tissues, it is liberated in larger quantities and is responsible for nettle rash [40]. The limiting amino acid (LAA) for all the samples was Met + Cys Table 8. This agrees with the report of FAO/WHO/UNU [31] that the EAA most often acting in a limiting capacity are Met (and Cys), Lys, Thr and Try. Try was not determined in this report.

\section{CONCLUSIONS}

This work has presented the nutritional quality of maize ogi from a composite mixture of white maize (Zea mays L.) and scarlet runner bean (Phaseolus coccineus L.) flours. The study showed that increased scarlet runner bean flour substitution gave progressive higher protein, crude fibre and ash contents of the fortified products with lower fat and carbohydrate contents. It was found that the samples were good sources of essential minerals and of high quality protein with adequate essential amino acids expected for the infants. However, the quality attributes of maize ogi can be adequately maintained at 70:30 and 60:40 scarlet runner bean seed substitution ogi mass ratios.

\section{ACKNOWLEDGEMENT}

M. O. Aremu (Ph.D) wishes to express his appreciation to Education Trust Fund (ETF), Nigeria for financial support rendered for this research work.

\section{REFERENCES}

[1] UNICEF. Breastfeeding: Foundation for a healthy future UNICEF, New York 1999.

[2] FAO. Sorghum and Millets in Human Nutrition. FAO Food Nutrition Series 27, Food and Agriculture Organization of the United Nations. Rome, Italy 1995.

[3] Khan NH, Bressan R. Preparation and nutritional quality of high protein food extracts from immature corn, whole soybean and dry whole milk. Plant Food Human Nutrition 1987; 37: 141-9.

[4] Adeyemi IA, Beckley O. Effect of period of maize fermentation and souring on chemical properties and amylograph pasting viscosity of ogi. J Cereal Sci 1986; 4: 353-60.

[5] Del Valle FR, Montemayo E, Bourges H. Industrial fortification of corn tortillas with oilseed flour by lime cooking of whole raw corn/soybean mixtures. J Food Sci 1976; 41: 349-351.

[6] Oyarekua MA, Eleyinmi AF. Comparative evaluation of the nutritional quality of corn, sorghum and millet ogi prepared by modified traditional technique. J Food Agric and Environ 2004; 2(2): 94-99.

[7] Enujiugha VN. Supplementation of ogi, a maize based infant weaning food, with African oil bean (Pentaclethra macrophylla Benth) seed. J Food Agric and Environ 2006; 4(2): 34-38.

[8] Ijarotimi OS, Oyewo MT, Oladeji BS. Chemical, functional and sensory properties of roasted bambara groundnut (Vigna subterranean L. Verdc) and cooking banana (Musa spp., ABB Genome) weaning diet. African J Food Sci 2009; 3(5): 139-46.

[9] Olaofe O, Adeyemi FO, Adediran GO. Amino acid and mineral composition and functional properties of some oil seeds. J Agric Food Chem 1993; 43: 878-81. 
[10] Aremu MO, Olaofe O, Basu SK, Abdulazeez G, Acharya SN. Processed cranberry bean (Phaseolus coccineus L.) seed flour for the African diet. Canadian J Plant Sci 2010; 90: 719-28.

[11] Adeyeye EI. Amino acid composition of six varieties of dehulled African yam bean (Sphenostylis stenocarpa) flour. Int J Food Sci 1997; 48: 345-57.

[12] Aremu MO, Olaofe O, Akintayo ET. Compositional evaluation of cowpea (Vigna unguiculata) and scarlet runner bean (Phaseolus coccineus) varieties grown in Nigeria. J Food Agric Environ 2006; 4(2): 39-43.

[13] Aremu MO, Olaofe O, Akintayo ET. A comparative composition of some Nigerian under-utilized legume flours. Pak J Nutri 2006; 5(1): 34-8.

[14] AOAC. Association of Official analytical Chemists. Official Methods of Analysis, $16^{\text {th }}$ ed. Washington, DC, AOAC 1995.

[15] James CS. Analytical Chemists of Foods. New York. NY, Chapman and Hall 1996.

[16] Spackman DH, Stein WH, More S. Automatic recording apparatus for use in the chromatography of amino acids. Anal Chem 1958; 301: 1190-206.

[17] Olaofe O, Akinatayo ET. Prediction of isoelectric points of legume and oil seed proteins from amino acid composition. J Technosci 2000; 4: 49-53.

[18] FAO. Amino acid content of foods and biological data in protein. FAO Nutritional studies. No. 34, FAO. Rome, Italy 1970.

[19] FAO/WHO. Protein quality evaluation report of joint FAO/WHO expert consultative FAO. Food and Nutrient FAO. Rome, Italy, 1991.

[20] Alsmeyer RH, Cunigham AE, Hapich ML. Equations predicted (PER) from amino acid analysis. Food Tech 1974; 28: 34-8.

[21] Nieman DC, Butterworth DE, Nieman CN. Nutrition. WmC: Dubuque I4, Brown Publishers 1992.

[22] Belschant AA, Lyon CK, Kohler GO. Sunflower, safflower, sesame and castor proteins. In: Pirie NW (ed.) Food Protein Sources: Cambridge, UK, Cambridge University Press 1975; pp. 79-104.

[23] Aremu MO, Olaofe O, Akintayo ET. Mineral and amino acid composition of two varieties of bambara groundnut (Vigna subterranean) and Kersting's groundnut (Kerstingiella geocarpa) flours. Int J Chem 2006; 16(1): 57-64.

[24] Fleck H. Introduction to Nutrition $3^{\text {rd }}$ ed New York, NY, Macmillan 1976; pp. 207-219.

[25] Shills ME. Magnesium. In: Fleck H. (ed.). Introduction to Nutrition. $3^{\text {rd }}$ ed. New York: Macmillan Publishing Co. Inc 1973; p. 215.
[26] Shills MYG, Young VR. Modern nutrition in health and disease. In: Nieman DE, Butterworth DE, Nieman $\mathrm{CN}$, eds. Nutrition: Dubuque, IA., Wm. C. Brown Publishers, 1992; pp. 276-82.

[27] UN (United Nations). Global Opportunities in reducing use of lead gasoline. IOMC/UNEP/CHEMICALS/98/9; Switzerland 1998.

[28] Adeyemi IA, Soluade EO. Development and quality evaluation of pawpaw-ogi. Plant Foods Human Nutr 1993; 44(3): 213-20.

[29] Aremu MO, Olaofe O, Orjioke CA. Chemical composition of bambara groundnut (Vigna subterranean), kersting groundnut (Kerstingiella geocarpa) and scarlet runner bean (Phaseolus coccineus) protein concentrates. La Rivista Italiana Delle Sostanze Grasse 2008; 85: 56-62.

[30] Aremu MO, Ekunode OE. Nutritional evaluation and functional properties of Clarias lazera (African catfish) from river Tammah in Nasarawa State, Nigeria. Am J Food Tech 2008; 3(4): 264-74.

[31] FAO/WHO/UNU. Energy and Protein Requirement. WHO Technical Report Series 724. WHO Geneva 1985.

[32] Robinson DE. Food Biochemistry and Nutritional value: London, Longman Sci Techn 1987.

[33] Oshodi AA, Olaofe O, Hall GM. Amino acid, fatty acid and mineral composition of pigeon pea (Cajanus cajan). Int J Food Sci Nutri 1993; 43: 187-91.

[34] Chavan UD, McKenzie DB, Shalindi F. Functional properties of protein isolates from beach pea (Lathyrus maritimus L.). Food Chem 2001; 74: 177-87.

[35] Aremu MO, Olonisakin A, Bako DA, Madu PC. Compositional studies and physicochemical characteristics of cashew nut (Anarcadium ocadentale) flour. Pak J Nutri 2006; 5(4): 328-33.

[36] Fennema OR (ed.). Principles of Food Chemistry Marcel Decker. New York 1985

[37] FAO. Sorghum and Millets in Human Nutrition FAO Food Nutrition Series 27. Food and Agriculture Organization of the United Nations. Italy 1995.

[38] Chafoorunissa S, Navasinga BS. Effect of leucine on enzymes of the tryptophan niacin metabolic pathway in rat liver and kidney. Biochem J 1973; 134(2): 425-30.

[39] Belavady B, Gopalem C. The role of leucine in the pathogenesis of canine black tongue and pellagra. Lancet 1969; 2: 956-7.

[40] Bingham S. Dictionary of Nutrition: London, Barrie and Jenkins 1977.

Received: June 04, 2011 Revised: July 15, 201

Accepted: August 03, 2011

(C) Aremu et al.; Licensee Bentham Open.

This is an open access article licensed under the terms of the Creative Commons Attribution Non-Commercial License (http://creativecommons. org/licenses/ by-nc/3. 0/) which permits unrestricted, non-commercial use, distribution and reproduction in any medium, provided the work is properly cited. 